\title{
Diachronic Study of Phonological Changes in Tiv Language
}

\author{
Terfa Aor ${ }^{a,}{ }^{*}$, Torkuma Tyonande Damkor ${ }^{b}$ \\ a Department of Linguistics and Nigerian Languages, National Institute for Nigerian Languages (NINLAN), Aba-Abia State of \\ Nigeria. \\ ${ }^{b}$ PhD Student, Benue State University, Makurdi, Benue State of Nigeria. \\ *Corresponding author Email: aorterfa80@gmail.com \\ DOI: https://doi.org/10.34256/ijll2111
}

Received: 19-03-2021, Revised: 24-03-2021; Accepted: 28-03-2021; Published: 30-03-2021

\begin{abstract}
All levels of language analysis are prone to changes in their phonology, morphology, graphology, lexis, semantics and syntax over the years. Tiv language is not an exception to this claim. This study investigates various aspects of phonological or sound changes in Tiv language. This paper therefore classifies sound changes in Tiv; states causes of sound changes in Tiv and explores implications of sound changes. The research design used in this paper is purposive sampling of relevant data. The instrument used in this paper is the observation method in which the author selected words that showed epenthesis, deletion and substitution. It has been noted that the use of archaic spellings in the Modern Tiv literatures shows their ancientness. Phonological change is not a deviation but a sign of language growth and changes in spellings result in changes in sounds. The author recommends that scholars should write papers or critical works on lexical/morphological, syntactic, semantic, graphological changes in Tiv language. Students should write projects, dissertations and theses on language change and diachronic linguistics. This study introduces Tiv historical linguistics and diachronic phonology which serve as catalysts for the study of Tiv language. The understanding of Tiv sound change provides students with a much better understanding of Tiv phonological system in general, of how Tiv phonology works and how the phonemes fit together
\end{abstract}

Keywords: Diachronic, Epenthesis, Monophthongisation, Phonological change, Synchronic

\section{Introduction}

Tiv, a major language that is spoken in Benue State of Nigeria, has tripartite connotations: the language itself is called Tiv Language; the tribe is also named a Tiv tribe and the progenitor of the Tiv race - ancestral father. The available literatures have shown that the Tiv language which was used in hundreds of years had undergone several changes in its phonology, graphology/orthography, morphology, syntax and semantics. It is clear that Tiv language existed in oral form for centuries before the White reduced it to its written form.

However, it is very cumbersome to categorically state the evolutionary changes that Tiv language had gone. This uncertainty stemmed from the fact that there is paucity of research or critical works on diachronic or historical linguistics and language change in Tiv. The revised edition of the Icighan Bibilo (2017) provided some of the changes that Tiv language had evolved. Recently, Aor (2020abcde) discussed phono-semantic study of English-Tiv falsefriends, graphological deviations in the Icighan Bibilo, onomatopoeias as a source of word formation in Tiv, reduplications in the Tiv grammar: classifications and functions None of the above studies mentioned language change or historical linguistics.

Considering the pervasiveness of sound change in the Tiv grammar, this study attempts to investigate various aspects of phonological or sound change in Tiv language. Language changes in Tiv are mainly conspicuous in its phonology which cannot be ignored in a hurry. This paper therefore classifies sound change; states causes of sound change and explores implications of sound change in Tiv language. 
For the ease of understanding this paper, there are two concepts that need to be reviewed. These concepts include diachronic or historical linguistics and phonological or sound changes.

\section{Diachronic or Historical Linguistics}

Aitchison (1992:287) asserts that diachronic and synchronic were formed in 20th century from Greek diâ (through) and sùn (together), respectively, and khrônos (time). Aitchison therefore defines diachronic linguistics as the study of the history of language. Campbell (1998:4)) asserts that historical linguistics deals with language change. (Crystal 2008:142) avers that in diachronic linguistics, languages are studied from the point of view of their historical development. O'Grady, Archibald and Katamba (2011:272) define historical linguistics as the 'description and explanation of language change.' Diachronic linguistics is sometimes called historical linguistics or linguistic diachrony. The primary concern of a historical linguist is to study various aspects of language change. Campbell's definition of diachronic linguistics is vitally important in this study.

The changes which have taken place in what the author designated as Old Tiv (OT) and Modern Tiv (MT) could be described in phonological, graphological, morphological, syntactical and semantic terms as diachronic phonology, graphology, morphology, syntax and semantics. Dimmendaal (2011:48) states that the purpose of diachronic phonology and the interpretations of innovations should indeed be to understand change not only in terms of a system undergoing it, but also in terms of the system that gave rise to it. Dimmendaal claims that phonological change does not just occur in any language but there are certain factors that engender such changes.

\section{Phonological or Sound Change}

All levels of language analysis are susceptible to change over time. According to Bisang, Hock and Winter (2009:8) and Millar (2015:48), sound change refer to changes in pronunciation of words. O'Grady, Archibald and Katamba $(2011,274)$ maintain that language variations or changes are particularly noticeable in the phonology of a language. Phonological change is synonymous with sound change. The author sees phonological change as an alteration from the segmental and suprasegmental features of any given phonology. These alterations may be as a result of elision, epenthesis, metathesis and substitution of sounds to the words that did not have such sound segments. Additionally, the introduction of certain diacritics such as tones - High ['], Low ['], Mid [-] or [_], HighLow ['], Low-High ['] to the existing words may result in different pronunciations or meanings.

Hickey (2016:203) observed that some of the [sound] changes were motivated by reanalysis on the part of language learners and some by gradual shifts in pronunciation by adult speakers. O'Grady, Archibald and Katamba (2011:274) categorised sound change into sequential changes (assimilation, dissimilation, epenthesis, deletion and metathesis); segmental change (deaffrication) and auditory based changes (substitution) $(/ \theta /-/ \mathrm{t} / ; / \mathrm{z} / \mathrm{s} / \mathrm{s}$ and $/ \mathrm{r} /$ - ///). Millar (2015:48) classified phonological change into two broad types: 'change in the sequence of speech sounds representing the pronunciation of a particular word or groups of similar words and the consequences of such change for the phonological system of an entire language. Phonological change is a main concern of diachronic linguistics.

\section{Literary Survey}

Studies on Tiv diachronic linguistic and language change are hard to come by. The researcher has not stumbled on any study or a book chapter that discussed phonological, graphological, morphological, syntactic and semantic changes in Tiv language. The author, being a native speaker and reader of Tiv language, has been able to observe from the available standard literatures that Tiv language had changed over time. Toryem and Gbaaikyo (2013:63) emphasize that '...the Tiv Bible seemed to be the only standard reference book for the Tiv grammar' and the revised edition of the Icighan Bibilo (2017) contains some of these changes. Some of the graphological changes are: hiihii - hii hii (Gen. 1:1) means beginning, kaa - kaa (Genesis 3:1) refers to said, ikese - ikyese (Ex. 2:3) is basket and ruamabera - rwamabera (Ex. 24:7) means scroll. The first example separates the two syllables [hii hi]; second example has subscript mark to indicate mid tone [kaa]; the third example involves palatal insertion $y$ [ikyese] and the last example replaces $/ \mho /$ with $/ \mathrm{w} /$.

Lexical or semantic changes are also found in the revised edition of the Icighan Bibilo when compared with the old edition of the Icighan Bibilo (2007). For example, tabernakel - iyol i tenti (Ex. 26:1): tabernacle; tasa - 
pelengi (Num. 7:67); Iwese - gbangi (Num. 7:67): plate; gbangbang - bokoti (Is. 5: 10): bucket, terafim amboravungu (Hos. 3:4): ancestral pipes; umasa - ukuese (Ezekiel 4:12): barley cakes. Continued reading of the new version of the Icighan Bibilo will soon send the former words to the department of semantic change!

Furthermore, sound change may be as a result of doubling vowels such as bang and baang (scarlet), wang and waang (immaculate), ihundu and ihuundu (dust); palatal insertion as in iveren - ivyeren (blessing), ihom and ihyom (hatred); deletion of vowels and consonants as in zough - zou (obtain), shighe - shie (time), uwegh - wegh (hand) and unwua - wua (guinea corn) and phonemic substitutions: l_umun - rumun (accept), Mlumun - Mrumun (I accept), nombol/nombul - nombor (tongue) and ipira - ipila (violence).

The above review indicated that there are changes in spellings of some Tiv words; some words that were once in vogue are gradually giving way to new ones and the sounds of some words have changed due to vowel and consonantal insertions, deletion of segments or syllables, replacement of sounds and phonemic substitutions. Lack of scholarly works to classify sound changes in Tiv, state causes of sound changes in Tiv and their implications propelled the author to embark on this study.

\section{Problem Statement}

All living human languages are susceptible to changes in their phonology, graphology, morphology, syntax and semantics over the years. These changes provide fertile ground for learners and speakers to add new lexical items that are in vogue and replace certain spellings that were faulted - thus enhancing correct pronunciations of words. Graphology and phonology tower above other changes in the grammar of Tiv. It has been noted that native and non-native speakers of Tiv language write Tiv words haphazardly as if there is there is no convention guiding Tiv words. However, it is clear that Tiv literatures that were written for over one hundred years differed from what is seen in the contemporary Tiv book. By way of illustration, Icighan Bibilo (The Holy Bible) that was written and published in 1966 greatly differed from its revised edition that was published in 2017.

An investigation into the study of Tiv language reviewed that there are paucity literatures on language change or diachronic linguistics. Diachronic linguistics is partially ventured into simply because it is energy-sapping and difficult to come by. As a result of this, it is highly cumbersome to cite any scholarly works on Tiv diachronic linguistics generally and diachronic phonology in particular, to add credence to this study. Sequel to the above claim, this paper attempts to fill the research gap that has existed in the diachronic study of phonological change in Tiv language by classifying sound changes in Tiv; stating causes of sound changes in Tiv and exploring implications of sound changes.

\section{Research Methodology}

The design used in this paper is purposive (non-probability) sampling. This sampling method involves deliberate selection of words that showed phonological changes. The selection was based on those words that involve addition, subtraction, replacement or transposition of phonemes.

The instrument used in this paper is through observation method. The authors picked sampled words that differ as result of a segment. The sampled words constituted primary data whereas journal articles and textbooks relevant to this study comprised secondary data.

The author intuitively jotted down those words that showed epenthesis, deletion and substitution. After the classifications of epenthesised, deleted and substituted words, they are presented in tables and analysed. To facilitate a meaningful interpretation of the raw information obtained through observation, a qualitative analysis of the data was carried out on each of the study objectives which are to:

i. classify sound changes in Tiv;

ii. state causes of sound changes in Tiv;

iii. explore implications of sound changes. 


\section{Data Analysis and Presentation}

This section deals with the causes of sound change such as auditory simplication, spelling pronunciation, analogy and language contact. It also classifies sound change in the Tiv grammar which comprises deletion, epenthesis and substitution. Lastly, this section discusses the effects of sound change in the Tiv grammar.

\section{Causes of Sound Change in Tiv Language}

Phonological changes occur in human languages. Some of the changes may be general while others may be peculiar to individual languages. O'Grady, Archibald and Katamba (2011:274-276) identified articulatory simplification, spelling pronunciation, cognitive factors (analogy and reanalysis), language contact as causes of language change. Most of the causes of sound changes identified by the above authors are vitally important in this study.

\section{Articulatory Simplification}

Articulatory simplification is one of the causes of sound change in Tiv language. It entails that sounds change to ease articulation. This change is made possible when letters are added, deleted or substituted so as to enhance easy pronunciation. Good examples of articulatory simplification are epenthesis, elision and substitution. In order to reduce the complex nature of articulating amngbian (relation) and amngbianev (relations), a voiced bilabial nasal $/ \mathrm{m} /$ is deleted in the MT spelling. In the standard MT orthography, the above two words are written as angbian and angbianev respectively. Additionally, vowels that were pronounced in the OT are now deleted in the MT to facilitate articulation of such words. For example, letter $i$ in ityôikyaa (reason) and uijuan (joints) are elided for the easy of pronunciation thus having new forms as ityôkyaa (reason) and ujuan.

Furthermore, for the ease of pronunciation, letter $y$ is inserted between consonants and vowels. Some native speakers and non-native speakers mispronounce words that were (are) not written with $y / \mathrm{j} /$. To enhance proper articulation of ihom (hatred), ikaior (the youth), igungu (hill) and ikur (nation) there is a need to insert $y$ in the OT spellings to become ihyom, ikyaior, igyungu and ikyur respectively.

Lastly, substitution of phonemes is another cause of sound change. Most words that $r$ and / were interchanged in the OT are now written with an I. The second edition of the Icighan Bibilo (2017) reflects this change. For example, ipira (violence), sure (died), yer (call), tebur (table) contained an $r$ in the OT spellings but the preferred spellings are ipila (violence), sule (died), yel (call) and tebul (table).

\section{Phonography or Spelling Pronunciation}

According to McArthur (1992:772), phonography is 'the art or practice of writing so as to represent sound as precisely as possible. Phonography is also known as phonetic spelling. In spelling pronunciation, words are pronounced to reflect more closely the spelling of words. The insertions of $i$ in place of $e$ in Lea (OT) and Lia (MT) for Leah and $a$ in lieu of er in Eseter and popeler (OT); Eseta and popela (MT) spellings for poplar approximate the pronunciations of the above words than their former spellings. Another example of spelling pronunciation is the lengthening of vowels to represent their pronunciations.The use of single vowels in dang (bad), eng (pure, immaculate), ving (quietness), bong (to stare), dông (tightly/tenaciously), ihundu (dust) does not reflect their actual pronunciations in the OT. In a bid to approximate or represent the actual pronunciations of the aforementioned words, double aa, ee, ii, oo, ôô and uu are used thus resulting in daang, eeng, ving, boong, dôông and ihuundu. This is graphically represented in the table 1 below:

Table 1 Phonetic Spellings involving Vowel Lengthening

\begin{tabular}{|l|l|l|l|l|l|}
\hline \multicolumn{2}{|c|}{ Old Tiv } & \multicolumn{2}{c|}{ Modern Tiv } & $\begin{array}{l}\text { Examples } \\
\text { of } \\
\text { Phonemes }\end{array}$ & $\begin{array}{l}\text { English } \\
\text { Gloss }\end{array}$ \\
\hline Word & Transcription & Word & Transcription & /æ/ \&/a:/ & bad \\
\hline dang & $/$ dæy/ & daang & $/$ da:n/ & (a) \\
\hline
\end{tabular}




\begin{tabular}{|c|c|c|c|c|c|}
\hline eng & /en/ & eeng & /e:p/ & /e/ \& /e:/ & immaculate \\
\hline ving & /VIn/ & viing & /VI:D/ & /I/ \&/I:/ & quietness \\
\hline bong & /bon/ & boong & /bo:n/ & /D/ \& /o:/ & to open wide \\
\hline dông & /doy/ & dôông & /do:n/ & /ว/ \&/د:/ & tightly \\
\hline ihundu & /Ihøndø/ & ihuundu & /Ihu:ndひ/ & /৩/ \&/u:/ & dust \\
\hline
\end{tabular}

\section{Analogy as a Cause of Sound Change}

Analogy shows the preference of speakers for regular patterns over irregular ones as in utakerada - ityakeda (books) and ikôl-laghen - ikyôrlaghen (prosperity). The $u$ in utakerada shows plurality in the old version of the Icighan Bibilo as seen in the Book of Jeremiah chapter 32:14. The author(s) of this book had false analogy that most plural nouns in Tiv are formed by the addition of $i$ before the stem. However, the MT plural formation of takeda (book) is ityakeda (books) which is preferred to untakerada. The spelling of ikôl-laghen which was used in Psalm 73:3 of the old edition of the Icighan Bibilo has replaced with its modernised spelling as ikyôrlaghen. The former was discarded because there is an absence of palatal insertion $/ \mathrm{j} /$; there is a substitution of an $r$ with an /and a presence of hyphen in the middle of single word.

\section{Language Contact}

The contact English and Tiv people had resulted in extensive borrowing of English loan-words. The process of obtaining new words from another language is called borrowing. Loan-words come with new phonemes that the recipient languages may not have. O'Grady, Archibald and Katamba (2011:274-276) affirmed that that the introduction of new phonemes or allophones and changes in their distribution are the effects that borrowing has on the sound system. It is obvious that Tiv language does not have voiceless inter-dental fricative so it is easier for words that have th $/ \theta /$ to be written as voiceless alveolar stop $/ t /$. For instance, the following words with $/ \theta /$ are pronounced /t/ (Table 2).

Table 2 Phonemic Replacement of English / $\theta /$ with Tiv /t/

\begin{tabular}{|c|c|c|c|c|}
\hline $\begin{array}{l}\text { English } \\
\text { Word }\end{array}$ & $\begin{array}{l}\text { Transcript } \\
\text { ion }\end{array}$ & $\begin{array}{l}\text { Loan- } \\
\text { word }\end{array}$ & $\begin{array}{l}\text { Transcripti } \\
\text { on }\end{array}$ & $\begin{array}{l}\text { New } \\
\text { Phoneme }\end{array}$ \\
\hline Esther & /esӨə/ & Eseta & /esetæ/ & $/ \mathrm{t} /$ \\
\hline Ethiopia & /І:Өгәәріә/ & Etiopia & /etıрріæ/ & $/ \mathrm{t} /$ \\
\hline Methuselah & $\begin{array}{l}\text { /məӨju:zələ } \\
\text { / }\end{array}$ & Metusela & /metðselæ/ & $/ t /$ \\
\hline Nazareth & /næzərəӨ/ & Nasareti & /næsæretI/ & $/ \mathrm{t} /$ \\
\hline Nathaniel & /nəӨænıə/ & Nataniel & /nætæniel/ & $/ \mathrm{t} /$ \\
\hline Ruth & /ru: $\theta /$ & Rutu & /roto/ & $/ \mathrm{t} /$ \\
\hline Seth & $/ \operatorname{se} \theta /$ & Setu & /seto/ & $/ \mathrm{t} /$ \\
\hline Timothy & /tıməӨi/ & Timoteu & /timnter/ & $/ \mathrm{t} /$ \\
\hline
\end{tabular}

Generally, languages have to change so as to accommodate new phonemes that are alien to the receiving language. It is imperative to reiterate that sound changes in Tiv language are occasioned by articulatory simplification, phonography or spelling pronunciation, analogy and language contact. The next section is the classification of sound change in Tiv. 


\section{Classification of Sound Change in Tiv}

\section{Deletion or Elision as a Sound Change Process in Tiv Grammar}

Deletion or elision occurs when the sound that was pronounced in the Old Tiv (OT) is lost or deleted in the Modern Tiv (MT). Elisions have been discussed based on two parameters: kinds of deleted segments and positions of elided segments. Kinds of deleted segments comprise vowe/and consonant deletions. Positions of elided segments dwell on aphaeresis (initial deletion), syncope (medial deletion) and apocope (final deletion).

\section{Deletion of Vowels (Monophthongs)}

Monophthong deletion deletes only one vowel. In the MT, the vowel letters that were pronounced are not even written in the contemporary standard orthography. The non-inclusion of vowels in certain words has resulted in the monophthong deletion (Table 3).

Table 3 Monophthong Deletion in the Modern Tiv

\begin{tabular}{|l|l|l|l|}
\hline Old Tiv & Modern Tiv & $\begin{array}{l}\text { Deleted } \\
\text { Vowels }\end{array}$ & Gloss \\
\hline ikyarikyase & ikyarkyase & $i$ & trembling \\
\hline ityôikyaa & ityôkyaa & $i$ & reason \\
\hline uijuan & ujuan & $i$ & joints \\
\hline uwegh & wegh & $u$ & hand \\
\hline
\end{tabular}

The above table has shown that letter $i$ is susceptible to deletion. For instance, ikyarikyase, ityôikyaa, uijuan and uwegh have four, four, three and two syllables respectively in the OT but with the deletion of $i$ and $u$ in the MT as shown in the above four words - ikyarkyase, ityôkyaa, ujuan and wegh - now have three, three, two and one syllables each.

\section{Diphthong Deletion or Reduction}

Some syllables or words that were considered diphthongs in the OT but such segments are now deprived of vowel cluster. A process of converting or changing a diphthong to a monophthong is referred to in this paper as dediphthongisation or monophthongisation. Diphthong deletion is prevalent in words that have ou or ough combinations. Some examples of diphthong reduction are presented in the Table 4:

Table 4 Diphthong Reduction in Modern Tiv

\begin{tabular}{|l|l|l|l|}
\hline Old Tiv & Modern Tiv & $\begin{array}{l}\text { Deleted } \\
\text { Vowels }\end{array}$ & Gloss \\
\hline $\begin{array}{l}\text { akaahôngorou } \\
\text { gh }\end{array}$ & $\begin{array}{l}\text { akaahôngoro } \\
\text { gh }\end{array}$ & $u$ & $\begin{array}{l}\text { abominable } \\
\text { things }\end{array}$ \\
\hline ikônough & ikyônogh & $u$ & chair/ throne \\
\hline louji & loji & $u$ & sickle \\
\hline tyough & tyogh & $u$ & head \\
\hline
\end{tabular}

The above table indicated diphthongs have been changed to monophthongs. The deletion of $u$ in akaahôngorough, ikônough, loujii and tyough reduces diphthong /ou/to a monophthong / $\mathrm{p} /$ in the following words: akaahôngorogh, ikônogh, loji and tyogh. 


\section{Deletion of consonants}

Apart from monophthong and diphthong deletions, consonants are also elided. Some words that were written with diagraph $g h / \mathrm{\gamma} /$ are now written without such a diagraph. This deletion is presented in the table 5 .

Table 5 Deletion of consonants in Modern Tiv

\begin{tabular}{|l|l|l|l|}
\hline Old Tiv & Modern Tiv & $\begin{array}{l}\text { Deleted } \\
\text { Consonants }\end{array}$ & Gloss \\
\hline anigheni & anieni & $g h$ & eight \\
\hline gbulugh gbulugh & gbullu gbullu & $g h$ & completely \\
\hline nzughul & nzuul & $g h$ & confusion \\
\hline shighe & shie & $g h$ & time; period \\
\hline shough shough & shou shou & $g h$ & tender \\
\hline
\end{tabular}

In the aforementioned words, diagraph $g h$ is deleted. The presence of $g h / \gamma /$ in Tiv words does not have much effect. The phoneme $/ \gamma /$ in the Tiv phonology is highly contested. A handful of scholars acknowledged its existence; other scholars bracketed it as a phoneme in Tiv and some scholars doubted its existence and importance. Those scholars that supported its existence cannot realise the so-called $/ \gamma /$ sound in words that have $g h$. Interestingly, deletion of $g h$ in the aforesaid words does not affect its syllabic structure (Table 6).

Table 6 Number of Syllables in Old Tiv and New Tiv

\begin{tabular}{|c|c|c|c|c|}
\hline \multicolumn{2}{|c|}{ Old Tiv } & \multicolumn{2}{|c|}{ Modern Tiv } & \multirow{2}{*}{$\begin{array}{l}\text { Number of } \\
\text { Syllables }\end{array}$} \\
\hline Word & $\begin{array}{l}\text { Transcripti } \\
\text { on }\end{array}$ & Word & $\begin{array}{l}\text { Transcript } \\
\text { ion }\end{array}$ & \\
\hline anigheni & /ænienI/ & anieni & /ænienI/ & 3 \\
\hline $\begin{array}{l}\text { gbulugh } \\
\text { gbulugh }\end{array}$ & $\begin{array}{l}\text { /gbひlひ } \\
\text { gbəlひ/ }\end{array}$ & $\begin{array}{l}g b \underline{u} / u \\
g b \underline{b} / u\end{array}$ & $\begin{array}{l}\text { /gbひlひ } \\
\text { gbəlひ/ }\end{array}$ & 4 \\
\hline nzughul & /pzu:I/ & nzuul & /gzu:I/ & 1 \\
\hline shighe & /shie/ & shie & /shie/ & 1 \\
\hline $\begin{array}{l}\text { shough } \\
\text { shough }\end{array}$ & / S০v Sov/ & shou shou & / গ০v গ০৩/ & 2 \\
\hline
\end{tabular}

\section{Aphaeresis in Modern Tiv}

The deletion of initial segment (vowel or consonant) is called aphaeresis. In the contemporary Tiv language, initial letters that were pronounced are now muted or silenced. Words whose initial letters were realised are now written without such letter and they are written the Table 7:

Table 7 Aphaeresis in Modern Tiv Language

\begin{tabular}{|l|l|l|l|}
\hline Old Tiv & Modern Tiv & $\begin{array}{l}\text { Vowel } \\
\text { Deletion }\end{array}$ & Meaning \\
\hline agbaga & gbaga & $a$ & prostitute \\
\hline agbinde & gbinde & $a$ & of viper \\
\hline uwagh & wagh & $u$ & river/ stream \\
\hline uwar & war & $u$ & grave \\
\hline
\end{tabular}




\begin{tabular}{|l|l|l|l|}
\hline uwegh & wegh & $u$ & hand \\
\hline uwer & wer & $u$ & month \\
\hline uwo & wo & $u$ & mountain \\
\hline uwua & wua & $u$ & guinea corn \\
\hline
\end{tabular}

It is indisputably clear that the deletion of the initial $a$ and $u$ in the above seven words shortened their syllables in the MT spellings and pronunciations. For example, agbaga and agbinde which were trisyllables in the OT are now bisyllables in the MT. Again, uwagh, uwar, uwegh, uwer and uwua that were bisyllables in OT are now monosyllables in MT.

\section{Syncope in Modern Tiv}

Syncope is the cancelling or deletion of a segment in the middle of words. Words whose medial letters were in the OT are now silenced in the MT. In Tiv language, all consonants and vowels are susceptible to deletion (Table 8).

Table 8 Syncope in Modern Tiv

\begin{tabular}{|l|l|l|l|}
\hline Old Tiv & Modern Tiv & $\begin{array}{l}\text { Deleted } \\
\text { Letters }\end{array}$ & Meanings \\
\hline amngbian & angbian & $m$ & relation \\
\hline amngbianev & angbianev & $m$ & relations \\
\hline ateghôtôutu & Ateatôutu & $g h$ & mid night \\
\hline Abiyatar & Abiatar & $y$ & Abiathar \\
\hline anigheni & anieni & $g h$ & eight \\
\hline uikuwan & ukyuan & $i \& w$ & rivers, brooks \\
\hline mbaihomov & mbahyomov & $i$ & enemies \\
\hline nzughul & nzuul & $g h$ & confusion \\
\hline shighe & shie & $g h$ & time \\
\hline taaikyôngo & taakyôngo & $i$ & wilderness \\
\hline
\end{tabular}

The above table shows that both consonants can be deleted in the middle of words. For instance, in amngbian and amngbianev, there is a deletion of $m$ which reduces the cluster of $m n g b$ to $n g b ; g h$ is elided in anigheni, nzughul, shighe which resulted in new spellings of words such as anieni, nzuul and shie. The insertion of letter $y$ in the OT has been deleted in the MT spelling and letter $i$ is deleted in ukyuan, mbahyomovand taaikyongo. Mbaihyomov and taaikyongo which were quadrasyllables in the OT are now trisyllables in MT.

\section{Apocope in Modern Tiv}

Apocope is a deletion of the final sound - vowel or consonant - in words. Diagraph $g h$ is often deleted at the end of words. When $g h$ is deleted at the end of the words, it changes a close syllable to an open one. Few examples of apocopations in MT are written in Table 9:

The deletion of $g h$ diagraph does not affect the pronunciations of the above words; it only 'smoothens' their articulation. A deletion $g h$ does not reduce the number of syllables but its absence changed the close syllables to open syllables. Generally, OT orthographic system permitted $g h$ in the spellings of the above words but MT does not allow the inclusion of $g h$. 
Table 9 Apocope in Modern Tiv

\begin{tabular}{|l|l|l|l|}
\hline Old Tiv & Modern Tiv & $\begin{array}{l}\text { Deleted } \\
\text { Letters }\end{array}$ & Meanings \\
\hline gbulugh gbulugh & gbullu gbullu & $g h$ & completely \\
\hline ough & ou & $g h$ & your \\
\hline zough & zou & $g h$ & obtain \\
\hline
\end{tabular}

\section{Epenthesis as a Sound Change Process in Tiv Grammar}

Epenthesis a universal phonological process in which a segment is added to an existing word for breaking consonant clusters, for repairing hiatus, for plurality and for questioning in Tiv language. This paper discusses vowel and consonant epentheses.

\section{Vowel Epenthesis and Lengthening in Modern Tiv}

The primary role of vowel epenthesis or insertion is the conversion or lengthening of short vowels to long vowels. This lengthening involves the addition of similar vowels to the existing ones. The addition of vowels does not change the meanings and the syllables of the existing words. It only affects the duration of articulation such words. Graphological changes have equally affected the realisation of the sounds. Native speakers of Tiv may articulate bang or baang (scarlet) and côhin and côhiin (little) by lengthening their pronunciations. However, based on the orthographies of the OT and MT, the shortening and lengthening processes are contrasted (Table 10):

Table 10 Vowel Lengthening in MT

\begin{tabular}{|c|c|c|c|}
\hline Old Tiv & Modern Tiv & Vowel Lengthening & Gloss \\
\hline bang & baang & /æ/ \&/a:/ & scarlet/red \\
\hline bong & boong & /D/ \& /o:/ & to open wide \\
\hline côhin & côhiin & /I/ \& /I:/ & little \\
\hline dang & daang & /æ/ \&/a:/ & bad \\
\hline dông & dôông & / / \& / / & tightly \\
\hline eng & eeng & /e/ \&/e:/ & immaculate \\
\hline fing fing & fiing fiing & /I/ \&/I:/ & dizzily \\
\hline gagh & gaagh & /æ/ \&/a:/ & fast \\
\hline gbev & gbeev & /e/ \& /e:/ & stumbling block \\
\hline gbong & gboong & /D/ \& /o:/ & loud shouting \\
\hline imagh & imaagh & /æ/ \&/a:/ & building \\
\hline iniav & iniaav & /æ/ \&/a:/ & sacrifices \\
\hline kweng & kweeng & /e/ \& /e:/ & bottomless \\
\hline mbautyav & mbautyaav & /æ/ \&/a:/ & soldiers \\
\hline nagh & naagh & /æ/ \&/a:/ & sacrifice \\
\hline tsung & tsuung & /v/ \&/u:/ & craving/ greatly \\
\hline ving & viing & /I/ \&/I:/ & quietness \\
\hline
\end{tabular}




\begin{tabular}{|l|l|l|l|}
\hline wang & waang & $/ æ /$ \&/a:/ & pure/immaculate \\
\hline
\end{tabular}

The above table has shown that in most words used single vowels which resulted in short vowels whereas the MT spellings doubled similar vowels which cause the above words to be longer in duration. For instance, bangbaang, dang - daang, gagh - gaagh, imagh - imaagh, iniav - iniaav, mbautyav - mbautyaav, nagh - naagh and wang - waang changed short a/æ/ to long aa /a:/ and eng - eeng, gbev - gbeev, kweng - kweeng converted e/e/ to ee/eI/. Furthermore, côhin - côhiin, fing fing - fiing fiing and ving - viing change short $i / 1 /$ to long ii/r:/; bong - boong and gbong - gboong converted short $0 / \mathrm{D} /$ to long $00 / 0: /$. Lastly, dông - dôong changed short $\hat{o} / \mathrm{J} /$ to long $\hat{o} \hat{o} / \mathrm{J}: /$.

\section{Consonant Insertions in Modern Tiv}

There is overkill of palata/ insertion /j/ in the MT words. In the OT orthography, most of the words that are now written with palatal epenthesis were not. The revised edition of the Icighan Bibilo ( The Holy Bible) contains such changes. The insertion of voiced palatal consonant 'smoothens' the pronunciation of words that bear them (Table 11).

Table 11 Consonant Insertions in Modern Tiv

\begin{tabular}{|c|c|c|c|}
\hline Old Tiv & Modern Tiv & $\begin{array}{l}\text { Epenthetic } \\
\text { Sound }\end{array}$ & Gloss \\
\hline adiguve & adigyuve & j & harp \\
\hline bughpupu & byughpupu & j & violent splashing \\
\hline ifan & ifyan & j & curse \\
\hline iferor & ifyeror & j & evil person \\
\hline igo & igyo & j & pig \\
\hline igungu & igyungu & $j$ & hill \\
\hline ihom & ihyom & j & enmity \\
\hline ikaior & ikyaior & j & the young \\
\hline ikav & ikyav & j & goods \\
\hline ikese & ikyese & $\mathrm{j}$ & basket \\
\hline ikôm & ikyôm & j & corpse \\
\hline ikon & ikyon & j & tree \\
\hline ikondo & ikyondo & j & cloth \\
\hline ikônough & ikyônogh & j & chair \\
\hline ikov ikov & ikyov ikyov & j & generations \\
\hline ikua ikua & ikyua ikyua & j & near \\
\hline mbaihomov & mbahyomov & j & enemies \\
\hline una & wuna & w & granary \\
\hline
\end{tabular}

The above table showed that palatal insertion does not come at the beginning of words and at the end of words. Palatal epenthesis constitutes medial consonant clusters such as $b y / \mathrm{bj} /, \mathrm{fy} / \mathrm{fj} /, g y / \mathrm{gj} /$ and $\mathrm{ky} / \mathrm{kj} /$. Lastly, there was no $w$ in una (barn or granary) in the OT spelling but there is an insertion of $w$ in the MT. The insertion of bilabial approximant /w/ provides onset to wuna. 


\section{Substitution as a Sound Change Process in Tiv Grammar}

Substitution is a replacement of one sound with another. This study hinges on vowel and consonant substitutions. Examples of substitutions are drawn from Tiv, English loan-words and of course Hausa words. The range of selection is so wide because some English and Hausa words have become part of Tiv vocabulary.

\section{Substitution of Vowels in the MT}

An in-depth reading of the old and revised versions of the Icighan Bible and other classical literature in Tiv revealed that the original letters of some words have been replaced with other spellings. Vowel substitution in MT is graphically presented in the Table 12 :

Table 12 Substitution of Vowels in the MT

\begin{tabular}{|l|l|l|l|}
\hline Old Tiv & Modern Tiv & Vowel Epenthesis & Gloss \\
\hline Eseter & Eseta & /e/ \&/æ/ & Esther \\
\hline kaara & keela & /a:/ \&/e:/; /r/ \& /l/ & there \\
\hline igbenda & igbinda & /e/ \&/I/ & ways or roads \\
\hline Lea & Lia & /e/ \&/I/ & Leah \\
\hline popeler & popela & /e/ \&/æ/ & poplar \\
\hline Rehobiam & Rehoboam & /I/ \&/D/ & Rehoboam \\
\hline Yerobiam & Yeroboam & /I/ \&/D/ & Jeroboam \\
\hline utakerada & ityakeda & /ひ/ \&/I/ & books \\
\hline
\end{tabular}

This substitution of letters could be as a result of approximating the pronunciation of words with their spelling as in Eseter and Eseta, Lea and Lia, popeler and popela. An average Tiv person will prefer the latter pronunciation Eseta, Lia and popela - to the former that ended in er and ea. For example, in the OT, ivowel substituted vowel $o$ Rehobiam and Yerobiam respectively. However, in the MT letter $o$ replaced the former letter $i$ as in Rehoboam and Yeroboam. Lastly, the plural form of a book in the OT was utakerada but in the MT it is ityakeda - thus letter $i$ substituted letter $u$.

\section{Substitution of Consonants in the MT}

The most commonly substituted letter is / and $r$ by the native speakers of Tiv. As far as the native speakers of Tiv are concerned, replacing / with $r$ is not a phonological 'crime'. The first edition of the Icighan Bibilo substituted $r$ with / and vice versa. However, the current edition of the Icighan Bibilo corrected that anomaly by preferring / in the place of $r$. It is paradox that the Dutch who reduced the Tiv language to writing could shuffle between $r$ and $/$ their spellings. The table 13 showed consonantal substitutions:

The above table clearly exposes that letters / and $r$ are prominently replaced letters as seen in the examples. Bilabial approximant /w/ replaced letter $u$ in Akwila and rwamabera. Again, $w$ in iwua is being replaced with letter $y$ $/ \mathrm{j} /$ in the MT spelling and pronunciation.

Table 13 Substitution of Consonants in the MT

\begin{tabular}{|l|l|l|l|}
\hline Old Tiv & Modern Tiv & Substitution & Gloss \\
\hline Akula & Akwila & $/ \& w i$ & Aquila \\
\hline asorabo & asolabo & $r \& /$ & sins \\
\hline hira & hila & $r \& /$ & temporary \\
\hline igbira & igbila & $r \& /$ & veins \\
\hline
\end{tabular}




\begin{tabular}{|l|l|l|l|}
\hline iwuese & iyuese & $w \& y$ & praise \\
\hline iwuhe & iyuhe & $w \& y$ & jealousy \\
\hline iwua & iyua & $u \& y$ & gift \\
\hline mbara & mbala & $r \& /$ & they \\
\hline ruamabera & rwamabera & $u \& w$ & scroll \\
\hline urugh & ulugh & $r \& /$ & pull, draw \\
\hline yer & yel & $r \& /$ & name or call \\
\hline
\end{tabular}

\section{Effects of Sound Change in Tiv Language}

Sound change has a lot of implications on phonological structure of Tiv language. Effects of phonological changes are shortening of syllables, converting close syllables to open syllables and vice versa, converting monoconsonants to consonant clusters, changing manner and place of articulation of phonemes, converting short vowels to long vowels, sound change causes lexical ambiguities.

\section{Changes in Syllable Structures}

Dimmendaal (2011:44) states that the various ways in which sound changes may affect the overall phonological structure of languages. He maintains that the phonological systems change, once the distribution of consonants or vowels and contexts where they are contrastive becomes affected. A close study of diachronic and synchronic sound change in Tiv indicated that syllables in some words were longer than the MT spellings. Shortening of syllables in the MT is shown in the table 14.

Table 14 Syllable Shortening in MT

\begin{tabular}{|l|l|l|l|}
\hline Old Tiv & Modern Tiv & $\begin{array}{l}\text { Deleted } \\
\text { Syllables }\end{array}$ & Gloss \\
\hline diamondi & diamon & $d i$ & diamond \\
\hline Mbaromanu & Mbaroma & $n u$ & Romans \\
\hline takerada & takeda & $r a$ & book \\
\hline
\end{tabular}

The above table indicates that in the OT translation, diamondi has four syllables while its MT translation (diamon) has two syllables. The last syllable of diamondi - $d i-$ is thus elided. Additionally, Mbaromanu has four syllables in the OT whereas its MT counterpart contains three syllables. Finally, takerada, a quadrasyllables, is changed to trisyllables by deleting re syllable. The effect of sound change is therefore the shortening of syllables.

Sound change is responsible for changing open syllables to close syllables. An open syllable ends with a vowel or a combination of a vowel and an $r$. There are minute instances of this in sound change in Tiv. These examples are shown below:

Table 15 Changing Open Syllables to Close Syllables

\begin{tabular}{|l|l|l|l|l|}
\hline \multicolumn{2}{|c|}{ Old Tiv } & \multicolumn{3}{c|}{ Modern Tiv } \\
\hline Open Syllable & Transcription & Close Syllable & Transcription & Gloss \\
\hline tebur & /tebu:/ & tebul & /tebəl/ & table \\
\hline tir & /tr:/ & til & /trl/ & stand \\
\hline yer & /je:/ & yel & /jel/ & call \\
\hline
\end{tabular}

The table 15 shows that the presence of letter $r$ in the OT spellings caused the preceding vowels to be longer. Letter / that comes at the end of MT does not elongate the preceding vowel. The above transcriptions indicated that the aforementioned MT words have close syllables. 
Conversely, close syllables in some OT words that contained diagraph gh are now deleted in the MT thus resulting in open syllables. These words that changed close syllable to open syllables are: shough shough, gbulugh gbulugh, zough and ough. The table 16 illustrates this change.

Naturally speaking, the authors does feel if there is a consonant after the aforesaid four words. Considering the irrelevance of $g h$ diagraph in the OT words, the MT deleted $g h$ thus reducing the close syllables to open syllables.

Table 16 Changing Close Syllables to Open Syllables

\begin{tabular}{|c|c|c|c|c|}
\hline \multicolumn{2}{|l|}{ Old Tiv } & \multicolumn{3}{|c|}{ Modern Tiv } \\
\hline Close Syllable & Transcription & Open Syllable & Transcription & Gloss \\
\hline gbulugh gbulugh & 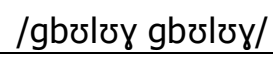 & gbulu gbulu & 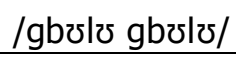 & totally \\
\hline ough & /ovy/ & ou & /ov/ & your \\
\hline shough shough & / Souy Sory / & shou shou & / Sov Sov/ & greenish \\
\hline zough & /zovy/ & zou & /z০ひ/ & obtain \\
\hline
\end{tabular}

\section{Conversion of Mono-consonants to Consonant Clusters}

Another effect of sound change in the phonology of Tiv is the conversion of mono-consonant to consonant clusters. This is the handiwork of palatal sound that is inserted a consonant and a vowel. When $/ \mathrm{j} /$ is inserted, it changes the single consonant to double consonant or consonant clusters. For instance, igo (pig), ivo (goat) and ikua (near) become igyo/ıgjo/, ivyo/ıvjo/ and ikyua //Ikjzæ/.

\section{Swapping of the Place of Articulation and the Position of the Tongue}

Furthermore, diachronic and synchronic sound changes result in the swapping of place of articulations or position of the tongue. Words that bilabial, alveolar, velar may be pronounced as if they are labio-dental, palatal, glottal and so on. For example,

i. Bilabial sound /w/ changed to palatal /j/ as in iwua to iyua (gift) and iwuese to iyuese (praise).

ii. Liquid/trill sound /r/ converted to lateral approximant /// as seen in hira to hila (temporary) and igbira to igbila (veins).

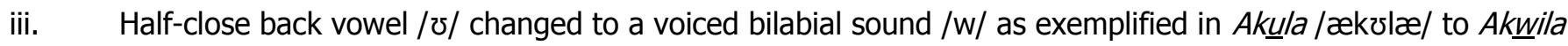
/ækwilæ/ (Aquila), ruamabera/rvæmæberæ/ to rwamabera /rwæmæberæ/ (scroll or Bible).

iv. Short half-close front vowel /I/ changed to short open front vowel /æ/ as evident in Yerobiam to Yeroboam (Jeroboam) and Rehobiam to Rehoboam (Rehoboam).

\section{Lexical Ambiguities}

The subtraction or addition of words may give rise to other words thus resulting in superfluity of meanings. For instance, the deletion of $u$ in MT word such as uwwua (guinea corn), uwwagh (river, stream, brook), uwwar (grave),

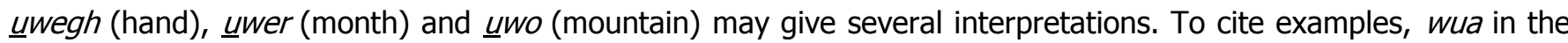
MT has the following meanings: guinea corn, to kill, to grind, ground (past tense of grind); war refers to as river, escape, grave, save, to grumble and so on.

\section{Research Implications}

From the foregoing, it has lucidly demonstrated that this study is highly inexhaustible. That means much research has to be carried out on language change. The following research implications have been made:

i. This study can be relevant to scholars who may want to work on lexical/morphological, syntactic, semantic, graphological changes in Tiv or other languages.

ii. The paper is may be vitally important to students who may wish to write projects, dissertations and 
theses on language change and diachronic linguistics.

iii. This study will be of great importance to those researching in the Department of Nigerian or African Linguistics and English language.

\section{Contributions to Scientific Community and Future Research}

i. This paper introduces Tiv historical and diachronic phonology.

ii. The understanding of Tiv sound change provides students with a much better understanding of Tiv phonological system in general, of how Tiv phonology works and how the phonemes fit together.

iii. This study contributes significantly to other sub-areas of linguistics (phonetics, phonology, graphology) and to linguistic theory.

\section{Conclusion}

The foregoing has indicated that language change is just a fact of life that cannot be prevented or avoided. Non-linguists might not know that that Tiv phonology has undergone some changes. The study has laid it bare that epenthesis, elision and phonemic substitutions are the major phonological changes in Tiv phonology. Also, phonological change is not a deviation but a sign of language growth. It can be stressed that all levels of language analysis show language change. Additionally, a change in spelling causes a change in sound.

Furthermore, vowel lengthening and palatal insertion reflect sound spellings; phonological changes affect vowel, consonant and syllabic structures. It has been observed that the spellings that were used in classical Tiv works differed greatly with the contemporary ones and the use of archaic spellings in the Modern Tiv literatures shows their ancientness.

Lastly, comprehending how sound change operates in Tiv language helps us explain that diachronic linguistics is a major thriving area of linguistics and it should be given the role it has played and continues to play in contributing towards the primary goals of linguistics in general.

\section{References}

Aitchison, J. (1992). Diachronic and synchronic. In McArthur, T. (1992). The Oxford companion to the English language. Oxford: Oxford University Press.

Aor, T., (2020a), A phono-semantic of English-Tiv false-friends, Taraba Journal of Humanities and Communications, 1(1) $112-133$.

Aor, T., (2020b). Graphological deviations in the Icighan Bibilo (Tiv Holy Bible): A step in enhancing standard Tiv orthography, Journal of Theatre and Visual, 3 (1) 41-64.

Aor, T., (2020c). Onomatopoeias as a word-formation in the Tiv Language, Journal of Theatre and Visual Art, 3 (1), 139-155.

Aor, T., (2020d). Reduplications in the Tiv grammar: Classifications and functions, Journal of linguistics and foreign languages, $1(2)$, 57-75.

Bisang, B., Hock, H.H., Winter, W., (2009). (Eds.). Language history, language change, and language relationship: An introduction to historical and comparative linguistics ( $2^{\text {nd }}$ rev. edn.). Berlin: Mouton de Gruyter.

Bowern, C., Evans, B., (2015). The Routledge handbook of historical linguistics, Routledge, London.

Campbell, L., (1998). Historical linguistics: An introduction. The MIT Press. Cambridge.

Crystal, D., (2008). A dictionary of linguistics and phonetics (6 $6^{\text {th }}$ ed.). Blackwell Publishing, Oxford.

Dimmendaal, J.G., (1988). The Turkana language, Foris, Dordrecht. 
Dimmendaal, J.G., (2011). Historical linguistics and comparative study of African languages, John Benjamins Publishing Company, Amsterdam.

Hamann, S., (2015). Phonological changes. The Routledge handbook of historical linguistics, Routledge, London.

Icighan Bibilo, (2007). The Holy Bible in Tiv, The Bible Society of Nigeria, Lagos.

Kyto, M., Pahta, P., (2016). The Cambridge handbook of English historical linguistics, Cambridge University Press, United Kingdom.

McArthur, T., (1992) The Oxford Companion to the English language, Oxford University Press, Oxford.

Millar, M.R., (2015). Trask's historical linguistics ( $3^{\text {rd }}$ ed.). Routledge, London.

O' Grady, W.B., Archibald J., Katamba, F., (2011). Contemporary Linguistics: An Introduction, $2^{\text {nd }}$ edition, Pearson Education, United Kingdom.

Toryem, M. M. \& Gbaaikyo, L. M. (2013). Towards forestalling Tiv language endangerment and extinction. Udu, T. T. and Soja, A. (ed). New perspective on Tiv language studies and development. Katsina-Ala: Gold Ink Company (60-75).

\section{Funding}

No funding was received for conducting this study.

Is this article screened for similarity?

Yes

\section{Conflict of interest}

The authors have no conflicts of interest to declare that they are relevant to the content of this article.

\section{About the License}

(C) The author(s) 2021. The text of this article is open access and licensed under a Creative Commons Attribution 4.0 International License 